\title{
Cytotoxic Effect of the Pentacyclic Oxindole Alkaloid Mitraphylline Isolated from Uncaria tomentosa Bark on Human Ewing's Sarcoma and Breast Cancer Cell Lines
}

Authors

Affiliation
Dolores García Giménez, Elena García Prado, Teresa Sáenz Rodríguez, Angeles Fernández Arche, Rocío De la Puerta

Department of Pharmacology, Faculty of Pharmacy, University of Seville, Seville, Spain
Key words

- Uncaria tomentosa

- Rubiaceae

- cat's claw

- oxindole alkaloid

- mitraphylline

- cytotoxic activity

\section{Abstract \\ $\nabla$}

Preparations from Uncaria tomentosa, a South American Rubiaceae, have been used in the Peruvian traditional medicine for the treatment of infective, inflammatory and tumoral processes. In this study, the pentacyclic oxindole alkaloid mitraphylline was isolated from the dried inner bark of this plant species, and its structure elucidated by analysis of NMR spectroscopic data. Mitraphylline was differentially identified from its stereoisomeric pair isomitraphylline by ${ }^{15} \mathrm{~N}-\mathrm{NMR}$. Its antiproliferative and cytotoxic effects have been tested on human Ewing's sarcoma MHH-ES-1 and breast cancer MT-3 cell lines, using cyclophosphamide and vincristine as reference controls. A Coulter counter was used to determine viable cell numbers, followed by the application of the tetrazolium compound MTS [3-(4,5-dime- thylthiazol-2-yl)-5-(3-carboxymethoxy phenyl)2-(4-sulfophenyl)-2H-tetrazolium] an inner salt. A colorimetric method was employed to evaluate cell viability in this cytotoxic assay. Micromolar concentrations of mitraphylline ( $5 \mu \mathrm{M}$ to $40 \mu \mathrm{M})$ inhibited the growth of both cell lines in a dosedependent manner. The $\mathrm{IC}_{50} \pm \mathrm{SE}$ values were $17.15 \pm 0.82 \mu \mathrm{M}$ for MHH-ES-1 and $11.80 \pm$ $1.03 \mu \mathrm{M}$ for MT-3 for 30 hours, smaller than those obtained for the reference compounds. This action suggests that the pentacyclic oxindole alkaloid mitraphylline might be a new promising agent in the treatment of both human sarcoma and breast cancer.

Supporting information available online at http://www.thieme-connect.de/ejournals/toc/ plantamedica

\section{Introduction}

\section{$\nabla$}

Uncaria tomentosa (Willdenow ex Roemer \& Schultes) DC. (Rubiaceae) is a Peruvian thorny liana, which is commonly known as "cat's claw" or "uña de gato". Peruvians have used it as a bark infusion for the treatment of a wide range of health problems such as cancer, gastric ulcers, viral infections, recovery from child birth, arthritis and other inflammatory processes $[1,2]$.

Many different chemical constituents have been isolated and identified in the extracts of cat's claw, including quinovic acid glycosides, sterols, tannins, procyanidins, flavonoids, ursane polyhydroxylated triterpenes and at least 17 oxindole alkaloids [3-9]. These compounds, acting in synergy, may be responsible for many pharmacological activities described for this plant [10]. The most prominent compounds are alkaloids. The chemical structure identification of these compounds from the Uncaria genus has been an ob- ject of study for decades [11-13]. It was found that two botanic chemotypes of Uncaria tomento$s a$ with different alkaloid patterns occur in nature. Most of the pharmacological activity has been attributed to the one which contains more pentacyclic (rather than tetracyclic) oxindole alkaloids $[14,15]$.

Numerous investigations concerning the anti-inflammatory properties of several extracts containing different quantities of pentacyclic oxindole alkaloids have been reported [16-18]. Moreover, it has been shown that cat's claw possesses immunostimulant properties as it induced human endothelial cells to release a lymphocyteproliferation regulating factor [19] and prolonged lymphocyte survival [20].

Furthermore, one of the most interesting properties of cat's claw extract is inhibiting cell proliferation. Thus, a commercially available water extract of the plant has demonstrated an antiproliferative effect in human leukemia and lymphoma 
cell lines [21]. In order to investigate the bioactive constituents responsible for its antiproliferative activity, Riva et al. [22] tested some chromatographic fractions of cat's claw extract on the MCF7 breast cancer cell line. More recently, Pilarski et al. [23] investigated the antiproliferative potency of several preparations with different quantitative and qualitative alkaloid contents on HL-60 acute promyelocytic human cells. In previous investigations, our group demonstrated a potent antiproliferative effect of the oxindole alkaloid mitraphylline on human glioma (GAMG) and neuroblastoma (SKN-BE) cell lines [24]. In the present study, we report the isolation and identification of this pentacyclic oxindole alkaloid from the inner bark extract of Uncaria tomentosa and further investigate the cytotoxic capacity of mitraphylline upon two other human tumoral cell lines: Ewing's sarcoma and breast cancer.

\section{Materials and Methods}

$\nabla$

\section{Bark extract}

The bark material from the Peruvian forest was supplied by the practitioner Dr. Carlos S. González and was identified in the Botanic Department of the San Lorenzo Chemical Sciences School from the Asuncion University in Paraguay. The bark extract was produced as follows: $500 \mathrm{~g}$ of Uncaria tomentosa dried inner bark were treated with ammonium hydroxide and dichloromethane. After filtration, the obtained solution was concentrated in vacuo to afford a residue, which was dissolved in a hydrochloric acid solution (3\%). Ammonium hydroxide and dichloromethane were added again. After concentration in vacuo, the purified alkaloid fraction was obtained as a brown residue and the yield was $0.15 \%$.

\section{Gas-chromatography/mass-spectrometry (GC/MS) analysis of the alkaloid fraction}

Gas-chromatography/mass-spectrometry analysis were realized, using a CARLO ERBA/KRATOS MS 80 RFA apparatus. Helium (99.99\%) was the carrier gas $(1 \mathrm{~mL} / \mathrm{min})$. One $\mu \mathrm{L}$ of the sample dissolved into dichloromethane was injected into the gas chromatograph. The injector and detector temperatures for the gas chromatograph were $275^{\circ} \mathrm{C}$ and $325^{\circ} \mathrm{C}$, respectively. The column oven temperature was increased linearly from $230^{\circ} \mathrm{C}$ to $300^{\circ} \mathrm{C}$ $\left(4^{\circ} \mathrm{C} / \mathrm{min}\right)$. The ionization mode was electron impact (EI). NBSL 1 B2 library was used to recognize all derivatives found in the fraction.

\section{Isolation and identification}

The dried residue of the alkaloid fraction $(0.5 \mathrm{~g})$ was subjected to a silica gel column chromatography, compacted with silicagel $0.063-0.2 \mathrm{~mm}(0.8 \times 25 \mathrm{~cm})$, followed by a gradient elution with various mixtures of $n$-hexane, $\mathrm{CH}_{2} \mathrm{Cl}_{2}$ and $\mathrm{MeOH}$. Twenty-five fractions of about $15 \mathrm{~mL}$ each were collected. In the fractions 14 to 16 , eluted with $\mathrm{CH}_{2} \mathrm{Cl}_{2} / \mathrm{MeOH}$ (9.5:0.5), an isolated compound was obtained by the method of TLC $\left(\mathrm{SiO}_{2}, \mathrm{CH}_{2} \mathrm{Cl}_{2} / \mathrm{MeCO}(5: 4) \mathrm{Rf}\right.$ : 0.83; ethyl ether/EtOAc ( $1: 1)$ Rf: $0.73 ; \mathrm{CH}_{2} \mathrm{Cl}_{2} / \mathrm{EtOH}(95: 5) \mathrm{Rf}$ : $0.68)$ and visualized as a brown and orange spot with the reagents sulphuric acid/ $\mathrm{CH}_{3} \mathrm{COOH} / \mathrm{H}_{2} \mathrm{O}(1: 20: 4)$. This was followed by heating at $120^{\circ} \mathrm{C}$ and the use of Dragendorff's reagent. ${ }^{1} \mathrm{H}$ and ${ }^{13} \mathrm{C}$ NMR experiments were performed for the compound identification using an AVANCE 500 spectrophotometer. The following 2D NMR experiments COSY-DQF, $\left({ }^{1} \mathrm{H}-{ }^{13} \mathrm{C}\right)-\mathrm{HSQC},\left({ }^{1} \mathrm{H}-{ }^{13} \mathrm{C}\right)-$ HMBC and NOESY correlation were used to elucidate its struc- ture. Futhermore, the $15 \mathrm{~N}$ chemical shifts of the isomeric oxindole alkaloids, using $\left({ }^{1} \mathrm{H}_{-}{ }^{15} \mathrm{~N}\right)$-HMBC experiments, were utilized to facilitate their characterization. The solvent used for NMR spectra was $\mathrm{CDCl}_{3}$.

\section{Cell cultures}

We used the human cell lines Ewing's sarcoma MHH-ES-1 and breast cancer MT-3 from DMSZ: Deutsche Sammlung von Mikroorganismen und Zellkulturen. Cell lines were seeded in $75 \mathrm{~cm}^{2}$ tissue culture flasks (Falcon). These cell lines were maintained in RPMI 1640 (Invitrogen-Gibco) supplemented with 10\% heat-inactivated fetal bovine serum according to the culture conditions suggested by the manufacturer. The cell lines were subcultured in $75 \mathrm{~cm}^{2}$ tissue culture flasks. The medium was renewed every two days and the cell cultures were incubated at $37{ }^{\circ} \mathrm{C}$ in a humidified atmosphere at $95 \%$ air and $5 \% \mathrm{CO}_{2}$.

\section{Drug treatments}

To determine the 50 inhibition concentration $\left(\mathrm{IC}_{50}\right)$, different concentrations $(5,10,20,30$ and $40 \mu \mathrm{M})$ of mitraphylline dissolved in ethanol were evaluated in the MHH-ES-1 and MT-3 cell lines. Cyclophosphamide (Merck Generics) and vincristine (Ciclum Farma) were used as reference controls at the same doses.

\section{Proliferation assay}

Cell proliferation was evaluated using the tetrazolium compound 3-(4,5-dimethylthiazol-2-yl)-5-(3-carboxy-methoxyphenyl)2-

(4-sulfophenyl)-2H-tetrazolium, inner salt (MTS), according to the manufacturer's instructions (CellTiter 96 Aqueous One-Solution Cell Proliferation Assay; Promega Corp.) and as described by Muñoz et al. [25]. Both cell lines were cultured for 4-5 days to let them grow as monolayer for MHH-ES-1 and in colonies (not necessarily as a monolayer) for MT-3. Cells were harvested by trypsinization and Trypan blue exclusion to determine cell viability. They were quantified using a Coulter counter. The experiments were made in 96-well plates, each well containing $10^{4}$ cells in a total volume of $100 \mu \mathrm{L}$. The plates were inoculated with drugs and incubated for a period (first doubling time) of $30 \mathrm{~h}$ (MT-3) or $28 \mathrm{~h}$ (MHH-ES-1), respectively. After that, $20 \mu \mathrm{L}$ of MTS reagent was added to each well. 90 min later, the samples were read at $492 \mathrm{~nm}$ in a multiscanner microplate reader (TECAN Spectra classic). The quantity of product, as measured by optical density, was directly proportional to the number of living cells. Each experimental condition was assayed in duplicate and all experiments were performed at least three times. The $\mathrm{IC}_{50}$ was calculated with a curve fitting parameter.

\section{Statistical analysis}

Results are expressed as mean \pm SE. All measurements were evaluated statistically using Student's t-test, taking $\mathrm{p}<0.05, \mathrm{p}<0.01$ and $\mathrm{p}<0.001$ as the levels of significance.

\section{Supporting information}

Gas-chromatogram of the alkaloid fraction and a table with comparison data of the different signs for mitraphylline and isomitraphylline obtained from the literature are provided as Supporting Information. 


\begin{tabular}{|c|c|c|c|c|c|}
\hline Position & $\delta_{1 \mathrm{H}}(\mathrm{ppm})$ & Multiplicity & $J(\mathrm{~Hz})$ & $\delta_{13 c}(\mathrm{ppm})$ & $\delta_{15 \mathrm{~N}}(\mathrm{ppm})$ \\
\hline 1 & 7.70 & s & - & - & 132.6 \\
\hline 2 & - & - & - & 180.9 & - \\
\hline 3 & 2.37 & $\mathrm{~m}$ & - & 74.6 & - \\
\hline 4 & - & - & - & - & 63.6 \\
\hline 5 & $3.36 ; 2.47$ & $\mathrm{~m} ; \mathrm{m}$ & - & 54.3 & - \\
\hline 6 & $2.47 ; 2.02$ & $\mathrm{~m} ; \mathrm{m}$ & - & 35.2 & - \\
\hline 7 & - & - & - & 55.6 & - \\
\hline 8 & - & - & - & 133.4 & - \\
\hline 9 & 7.17 & d & 7.8 & 123.0 & - \\
\hline 10 & 7.01 & td & $7.7 ; 1.1$ & 122.6 & - \\
\hline 11 & 7.16 & td & $7.6 ; 1.2$ & 128.0 & - \\
\hline 12 & 6.83 & d & 7.6 & 109.5 & - \\
\hline 13 & - & - & - & 140.7 & - \\
\hline 14 & $2.37 ; 1.17$ & $\mathrm{~m} ; \mathrm{dd}$ & $-; 11.8,10.7$ & 28.4 & - \\
\hline 15 & 2.09 & $\mathrm{~m}$ & - & 30.5 & - \\
\hline 16 & - & - & - & 107.0 & - \\
\hline 17 & 7.40 & d & 1.35 & 154.1 & - \\
\hline 19 & 4.35 & qd & $6.6 ; 3.1$ & 73.9 & - \\
\hline 20 & 2.08 & $\mathrm{~m}$ & - & 40.5 & - \\
\hline 21 & $3.19 ; 1.82$ & $d d ; t$ & $10.4,2.5 ; 10.4$ & 54.3 & - \\
\hline 22 & - & - & - & 167.1 & - \\
\hline 23 & 3.57 & $\mathrm{~s}$ & - & 50.7 & - \\
\hline 24 & 1.09 & d & 6.6 & 14.9 & - \\
\hline
\end{tabular}

Table 1 Signs, multiplicity and coupling constants ( () from the NMR spectra of the isolated compound ( $\delta$ values, in $\mathrm{CDCl}_{3}$ ).

s: singlet, d: doublet, t: triplet; dd: double doublet, td: triple doublet, cd: quadruple doublet, m: multiple

\section{Results and Discussion}

$\nabla$

One of the most recognized alkaloids in Uncaria is the oxindole alkaloid mitraphylline which has been identified in 20 of the 34 species [2]. Alkaloids have been mainly separated and identified by HPLC [13], but we used GC/MS to recognize the alkaloid profile of a purified alkaloid fraction as previously described by Phillipson and Hemingway [11]. In the gas-chromatogram (Fig. 1S, Supporting Information) a main peak could be observed, at a retention time of $24.22 \mathrm{~min}$. This compound represented $87.3 \%$ of the total alkaloid fraction. Its mass spectrum EI-MS data were: $\mathrm{m} / \mathrm{z}$ 368 ( $\left.\mathrm{M}^{+}, 63\right), 223$ (100), 208 (35),180 (2), 146 (6), 145 (6), 144 (7), 130 (13), and 69 (30). Its molecular formula was determined to be $\mathrm{C}_{21} \mathrm{H}_{24} \mathrm{~N}_{2} \mathrm{O}_{4}$.

Approximately $200 \mathrm{mg}$ of white crystal were obtained from $500 \mathrm{mg}$ of the dried residue of the alkaloid fraction by silica gel column chromatography. Data from the NRM experiments performed with the isolated compound are listed in Table 1. These signals were in agreement with those reported in the literature [6]. Data from the $\left({ }^{1} \mathrm{H}-{ }^{15} \mathrm{~N}\right)-\mathrm{HMBC}$ spectrum allowed us to confirm the differential structural characteristics of mitraphylline compared to its stereoisomeric pair isomitraphylline (Table 1S, Supporting Information). (Copies of the original spectra are obtainable from the author of correspondence.) These have already been used by other authors to distinguish between stereoisomeric pairs of oxindole alkaloids [6,26,27]. The structure of the alkaloid is illustrated in 0 Fig. 1. These chemical pentacyclic types of alkaloids are considered to be biochemical marker of cat's claw and are responsible, in part, for its immunomodulatory and cytostatic activities.

From our experiments, growth inhibition of the MHH-ES-1 sarcoma and MT-3 breast cancer cell lines was observed after the addition of increasing concentrations of mitraphylline at the first doubling time of incubation. Moreover, the treatment of both cell lines with the alkaloid resulted in a concentration-dependent cytotoxicity. The calculated mitraphylline concentration required

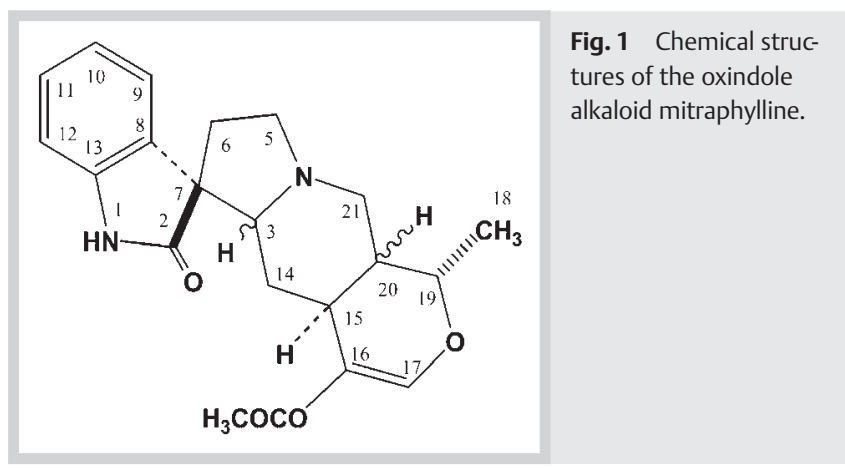

for a $50 \%$ reduction in $\mathrm{MHH}-\mathrm{ES}-1$ sarcoma proliferation $\left(\mathrm{IC}_{50}\right)$ was $17.15 \pm 0.82 \mu \mathrm{M}$ for 30 hours. This dose was smaller than those calculated for cyclophosphamide and vincristine: $67.60 \pm$ $2.30 \mu \mathrm{M}$ and $39.16 \pm 1.21 \mu \mathrm{M}$, respectively. For MT-3 human breast cancer cells, the alkaloid $\mathrm{IC}_{50}$ was $11.80 \pm 1.03 \mu \mathrm{M}$ for 30 hours. Also in this case, the dose is smaller than those for cyclophosphamide and vincristine, $38.01 \pm 2.21 \mu \mathrm{M}$ and $44.66 \pm$ $2.72 \mu \mathrm{M}$, respectively. Maximum inhibition was observed when mitraphylline was present at a concentration of $40 \mu \mathrm{M}$ during the culture period ( $\mathrm{p}<0.001$ against the control untreated cells) for both tumoral cell lines. At the first doubling time, a strong decrease in the cell number of the two lines studied was found at intermediate concentrations ( $p<0.05$ at $10 \mu \mathrm{M} ; \mathrm{p}<0.01$ at $20 \mu \mathrm{M}$ and $\mathrm{p}<0.001$ at $30 \mu \mathrm{M}$ ) and almost no remaining living cells were observed at the maximum concentrations.

Other authors have demonstrated a cytotoxic potency of different pentacyclic alkaloids. One of these studies shows uncarine $\mathrm{F}$ as the most antiproliferative alkaloid towards leukemic cells [28]. In another study, Muhammad et al. [6] isolated and identified five steroisomer oxindole alkaloids and reported uncarine $\mathrm{D}$, with $\mathrm{IC}_{50}$ values in a range of $30-35 \mu \mathrm{g} / \mathrm{mL}$, as the most cytotoxic from them, against three tumoral human cell lines. On the other 
hand, Bacher et al. [29] found a strong apoptotic effect of pteropodine and uncarine $\mathrm{F}$ on acute leukemic lymphoblasts, but mitraphylline was not as effective as them against this cell line. As it can be observed, there is no full agreement on the cytotoxicity potential of these alkaloids, which show differential sensitivity towards different tumoral cell lines.

On a previous work, we had already observed that mitraphylline had stronger antiproliferative effect than vincristine and cyclophosphamide on two human brain tumoral cell lines [24] using the same colorimetric assay. Here, we report for the first time on the cytotoxic effect of the highly purified mitraphylline alkaloid isolated from the bark of Uncaria tomentosa on a sarcoma (MHH-ES-1) and a breast cancer (MT-3) cell line. This action suggests that mitraphylline might be a new promising agent in the treatment of both human sarcoma and breast cancer, besides brain cancer.

\section{Acknowlegements}

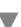

The authors would like to acknowledge to Dr. Miguel Muñoz from Hospital Universitario Virgen Del Rocío de Sevilla, for the excellent help in the development of the antiproliferative assays. Financial support by "Consejo General de Colegios Farmacéuticos de Andalucía" is acknowledged.

\section{References}

1 Keplinger K, Laus G, Wurm M, Dierich MP, Teppner H. Uncaria tomentosa (Willd.) DC. ethnomedicinal use and new pharmacological, toxicological and botanical results. J Ethnopharmacol 1999; 64: 23-34

2 Heitzman ME, Neto CC, Winiarz E, Vaisberg AJ, Hammond GB. Ethnobotany, phytochemistry and pharmacology of Uncaria (Rubiaceae). Phytochemistry 2005; 66: 5-29

3 Montoro P, Carbone V, Quiroz De Dioz J, De Simone F, Pizza C. Identification and quantification of components in extracts of Uncaria tomentosa by HPLC-ES/MS. Phytochem Anal 2004; 15: 55-64

4 Kitajima M, Hashimoto K, Yokoya M, Takayama H, Sandoval M, Aimi N. Two new nor-triterpene glycosides from peruvian "Uña de Gato" (Uncaria tomentosa). J Nat Prod 2003; 66: 320-323

5 Kitajima M, Yokoya M, Takayama H, Aimi N. Synthesis and absolute configuration of a new 3, 4-dihydro-beta-carboline-type alkaloid, 3 , 4-dehydro-5(S)-5-carboxy-strictosidine, isolated from Peruvian Uña de Gato (Uncaria tomentosa). Chem Pharm Bull 2002; 50: 1376-1378

6 Muhammad I, Dunbar DC, Khan RA, Ganzera M, Khan IA. Investigation of Uña De Gato I. 7-Deoxyloganic acid and ${ }^{15} \mathrm{~N}$ NMR spectroscopic studies on pentacyclic oxindole alkaloids from Uncaria tomentosa. Phytochemistry 2001; 57: 781-785

7 Muhammad I, Khan IA, Fischer NH, Fronczek FR. Two stereoisomeric pentacyclic oxindole alkaloids from Uncaria tomentosa: uncarine C and uncarine E. Acta Crystallogr C 2002; 57: 480-482

8 Aquino R, De Simone F, Vincieri FF, Pizza C. New polyhydroxylated triterpenes from Uncaria tomentosa. J Nat Prod 1990; 53; 559-564

9 De Matta SM, Monache FD, Ferrari F, Marini-Bettolo GB. Alkaloids and procianidins of Uncaria sp. from Peru. Pharmacology 1976; 31: 527535

10 Rizzi R, Re F, Bianchi A, De Feo V, De Simone F, Bianchi L, Stivala LA. Mutagenic and antimutagenic activities of Uncaria tomentosa and its extracts. J Ethnopharmacol 1993; 38: 63-77
11 Phillipson JD, Hemingway SR. Chromatographic and spectroscopic methods for the identification of alkaloids from herbarium samples of the genus Uncaria. J Chromatogr 1975; 105: 163-178

12 Laus G, Keplinger D. Separation of stereoisomeric oxindole alkaloids from Uncaria tomentosa by high performance liquid chromatography. J Chromatogr A 1994; 662: 243-249

13 Ganzera M, Muhammad I, Khan RA, Khan IA . Improved method for the determination of oxindole alkaloids in Uncaria tomentosa by high performance liquid chromatography. Planta Med 2001; 67: 447-450

14 Philp RB. Herbal-drug interaction and adverse effects. An evidencebased quick reference guide. New York: McGraw-Hill Editions; 2004: 63-65

15 Reinhard KH. Uncaria tomentosa (Will.) DC: cat's claw, uña de gato, or saventaro. J Altern Compl Med 1999; 5: 143-151

16 Sandoval M, Charbonnet RM, Okuhama NN, Roberts J, Krenova Z, Trentacosti AM, Miller MJS. Cat's claw inhibits TNF [alpha] production and scavenges free radicals: role in cytoprotection. Free Radic Biol Med 2000; 29: 71-78

17 Sandoval-Chacon M, Thompson JH, Zhang XJ, Liu X, Mannick EE, Sadowska-Krowicka H, Charbonnet RM, Clark DA, Miller M. Antiinflammatory actions of cat's claw: the role of NF-kB. Aliment Pharmacol Ther 1998; $12: 1279-1289$

18 Aguilar JL, Rojas P, Marcelo A, Plaza A, Bauer R, Reininger E, Klaas CA, Merfort I. Antiinflammatory activity of two different extracts of Uncaria tomentosa (Rubiaceae). J Ethnopharmacol 2002; 81: 271-276

19 Wurm M, Kacani L, Laus G, Keplinger K, Dierich MP. Pentacyclic oxindole alkaloids from Uncaria tomentosa induce human endothelial cells to release a lymphocyte-proliferation regulating factor. Planta Med 1998; 64: 701-704

20 Akesson C, Pero RW, Ivars F. C-Med 100, a hot water extract of Uncaria tomentosa, prolongs lymphocyte survival in vivo. Phytomedicine 2003; 10: $23-33$

21 Sheng Y, Pero RW, Amiri A, Bryngelsson C. Induction of apoptosis and inhibition of proliferation in human tumor cells treated with extracts of Uncaria tomentosa. Anticancer Res 1998; 18: 3363-3368

22 Riva L, Coradini D, Di Fronzo G. The antiproliferative effects of Uncaria tomentosa extracts and fractions on the growth of breast cancer cell line. Anticancer Res 2001; 21: 2457-2461

23 Pilarski R, Poczekaj-Kostrzewska M, Ciesiolka D, Szyfter K, Gulewicz K. Antiproliferative activity of various Uncaria tomentosa preparations on HL-60 promyelocytic leukemia cells. Pharmacol Rep 2007; 59: 565-572

24 García Prado E, García Gimenez MD, De la Puerta Vazquez R, Espartero Sanchez JL, Sáenz Rodríguez MT. Antiproliferative effects of mitraphylline, a pentacyclic oxindole alkaloid of Uncaria tomentosa on human glioma and neuroblastoma cell lines. Phytomedicine 2007; 14: 280284

25 Muñoz M, Rosso M, Pérez A, Coveñas R, Rosso R, Zamarriego C, Piruat II. The NK1 receptor is involved in the antitumoral action of L-733, 060 and in the mitogenic action of substance $P$ on neuroblastoma and glioma cell lines. Neuropeptides 2005; 39: 427-432

26 Seki A, Takayama H, Aimi N, Salai SL, Ponglux D. A nuclear magnetic resonance study on the eleven stereoisomers of heteroyohimbine-type oxindole alkaloids. Chem Pharm Bull 1993; 41: 2077-2086

27 Paradowska K, Wolniak M, Pisklak M, Gliński JA, Davey MH, Wawer I. ${ }^{13} \mathrm{C},{ }^{15} \mathrm{~N}$ CPMAS NMR and GIAO DFT calculations of stereoisomeric oxindole alkaloids from Cat's Claw (Uncaria tomentosa). Solid State Nucl Magn Reson 2008; 34: 202-209

28 Stuppner H, Sturm S, Geisen G, Zillian U, Konwalinka G. A differential sensitivity of oxindole alkaloids to normal and leukemic cell lines. Planta Med 1993; 59: A583

29 Bacher N, Tiefenthaler M, Sturm S, Stuppner H, Ausserlechner MJ, Kofler $R$, Konwalinka G. Oxindole alkaloids from Uncaria tomentosa induce apoptosis in proliferating, G0/G1-arrested and bcl-2-expressing acute lymphoblastic leukaemia cells. Br J Haematol 2006; 132: 615-622 